\title{
Effects of different tillage methods on maize (Zea mays L.) root development in andosol
}

\author{
Dayou, E. D. ${ }^{1 *}$, Zokpodo, B. L. ${ }^{1}$ and Rakoto, B. ${ }^{2}$ \\ ${ }^{1}$ Faculty of Agronomic Sciences, School of Environmental Management, University of Abomey-Calavi, 01 BP 526 \\ Cotonou, Benin. \\ ${ }^{2}$ Department of Agriculture, School of Agronomic Sciences, University of Antananarivo, BP 175 Antananarivo (101), \\ Madagascar.
}

Accepted 3 April, 2017

\begin{abstract}
Ploughing can modify or destroy the physical properties of the soil and influences crop root development. This study aimed to understand the effects of four different tillage methods on maize root development in an andosol. Ploughing depth, soil refinement, root extension and root development pattern of maize were the main parameters observed. The treatments were arranged in random complete block with three replicates. The software Rstat was used to do analysis of variance on the data. It was noted that ploughing with animal traction facilitates more maize root development both lateral and vertical, followed by tractor ploughing and then with the cultivator. Ploughing with the tractor offers the largest area of root concentration. In addition, the number of fine roots for all ploughing, with the exception of manual ploughing, is increased beyond 20 $\mathrm{cm}$. The relationship between apparent soil density and the number of roots developed by maize is non linear with a threshold at which root density becomes inversely proportional to the apparent soil density. Thus, in each horizon $10 \mathrm{~cm}$ thick to less than $30 \mathrm{~cm}$ deep, the maximum number of root about 67 roots is reached when the apparent soil density is closed to $9.8 \pm 1.0 \mathrm{kN} / \mathrm{m}^{3}$.
\end{abstract}

Keywords: Tillage, root, maize, andosol, Antsirabe-Madagascar.

*Corresponding author. E-mail: phreddoss1@yahoo.fr. Tel : +22967904166.

\section{INTRODUCTION}

The fact that pedoclimatic conditions in arid and semi-arid areas make annual plant growth very difficult (Nicou et al., 1993), it is necessary to switch to agricultural tools that work best on the soil. One of the methods for achieving improvements in soil physical properties of the land is through tillage in all its forms. Thus, through improved soil structure and the disappearance of shrinkage cracks, ploughing has a direct impact on soil hydrology (Jenhaoui and Raclot, 2011). Despite these advantages, ploughing creates excessive soil refinement and compaction (Roisin, 2006), and can negatively influences soil biology by reducing, for example, the number of earthworms (Andriamanantena, 2006). Evaluation of the root system is thus a key element of crop diagnosis to assess the agronomic quality of a soil condition. This makes it possible to explain or to predict the behavior of plant in relation to different ploughing methods (Chopart, 1999), since there is a positive correlation between the root development of certain crops and their yield (Zoelinirina, 2007). This study evaluates the effects of four ploughing methods on maize root development in an andosol.

\section{METHODOLOGY}

\section{Location of the study site}

The studies were conducted in the Antsirabe Agricultural Machinery Training and Application Center (CFAMA) in the Malagasy Highlands (Figure 1).

Antsirabe has been chosen for this study because it is one of the major maize processing area on the Island. CFAMA has experience in mechanization and the availability of agricultural mechanics and equipments for the implementation of the works. The climate of the area is temperate tropical characterized by unimodal rainfall : a 


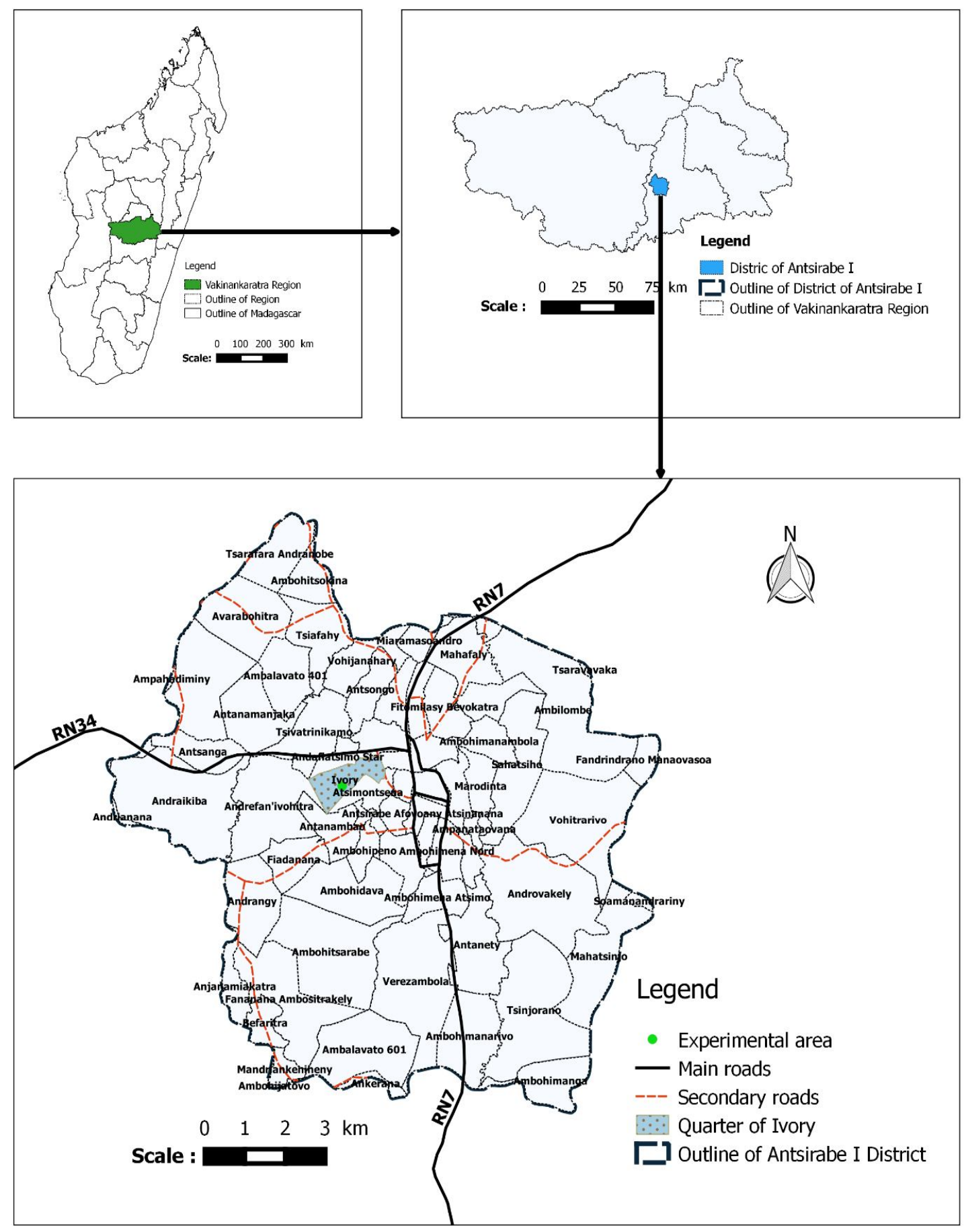

Figure 1. Map of the location of the experimental site.

moderately warm rainy season from November to April and a relatively cold dry season from may to october. The mean annual rainfall varies from 1200 to $2000 \mathrm{~mm}$. Precipitation with hail stones is frequent during the summer. The average annual temperature is less than or equal to $20^{\circ} \mathrm{C}$ and decreases by $0.6^{\circ} \mathrm{C}$ every $100 \mathrm{~m}$ under the effect of altitude (Raboin et al., 2013). The region is rarely affected by cyclones, but the abundance of rains during their passage can cause flooding in the lowlands and erosion on the higher parts of the watersheds (MAEP, 2003). The system is installed on an andosol according to the World Baseline for Soil Resources (FAO et al., 1999). This corresponds to the class of andosols of the French classification (CPCS, 1967) and to the suborder of the order of inceptisols according to the American soil classification (Wambeke et al., 1986 ; FAO and Unesco, 1975). Table 1 shows the soil compositions.

These analyzes were carried out at the Soil Laboratory of School of Agricultural Sciences and the Laboratory of Radiolsotopes of the University of Antananarivo and at the National Laboratory of Public 
Table 1. Soil characteristics.

\begin{tabular}{lcccccc}
\hline Parameters & & L0 & L1 & L2 & L3 & L4 \\
\hline Depth of sampling & $\mathrm{cm}$ & 30 & 10 & 15 & 15 & 25 \\
Clays $(<2 \mu \mathrm{m})$ & $\%$ & 49.20 & 48.65 & 48.9 & 49.11 & 49.76 \\
Fine limon $(2-20 \mu \mathrm{m})$ & $\%$ & 31.6 & 31.21 & 31.95 & 31.83 & 31.8 \\
Coarse limon $(20-50 \mu \mathrm{m})$ & $\%$ & 11.3 & 11.36 & 11.65 & 11.55 & 11.59 \\
Fine sand $(50-200 \mu \mathrm{m})$ & $\%$ & 4.22 & 4.58 & 4.34 & 4.43 & 4.01 \\
Coarse sand $(200-2000 \mu \mathrm{m})$ & $\%$ & 2.55 & 3.13 & 3.08 & 2.99 & 2.81 \\
Organic material & $\%$ & 12.06 & 11.65 & 12.19 & 12.80 & 12.12 \\
$\mathrm{pH}$ & & 6.16 & 6.06 & 6.01 & 6.19 & 6.08 \\
\hline
\end{tabular}

Works and the Building of Antananarivo.

\section{RESEARCH METHODOLOGY}

Manual ploughing will be done with a spade (angady) at a depth of $10 \mathrm{~cm}$ (L1), animal ploughing with a pair of oxen and a plow with 30 $\mathrm{cm}$ of width for $15 \mathrm{~cm}$ depth (L2), Ploughing with a cultivator plus $30 \mathrm{~cm}$ reversible plow at a depth of $15 \mathrm{~cm}$ (L3) and ploughing with a tractor coupled with a reversible plow of $50 \mathrm{~cm}$ as width by $25 \mathrm{~cm}$ depth (L4). No-tillage (L0) was used as a check treatment. Large clods were obtained after ploughing with the tractor, which forced to use the disc harrow to refine the plots concerned. It is a complete random block device. These treatments were carried out each with three (3) replications. The land with an area of $1548 \mathrm{~m}^{2}$ was divided into three (3) blocks perpendicularly to the average slope $(2.75 \%$ from west to east). Each block was divided into five (5) plots. A corridor of $3 \mathrm{~m}$ surrounds each of the elementary parcels. A total of 15 basic plots of $40 \mathrm{~m}^{2}$ each. Beans and soybeans are the last crop grown on the parcel under mechanical tillage.

\section{Plant material}

Maize was chosen as test crop for study as it plays an important role in the diet of populations of Madagascar, animal feeds formulation and in industry (brewing). Tombontsoa variety, common to maize farmers in South Madagascar was used. This variety is matures early with a vegetative cycle of less than 90 days with good forage yield. In addition to its tolerance to water stress and viruses, this variety wisthads lodging incidencies and performs better compared to ohter varieties such as the Irat 200 and Cirad 412 (CPSA, 2016). The maize was sown with a spacing of $80 \mathrm{~cm} \mathrm{x}$ $50 \mathrm{~cm}$ at two seeds per pole where $5 \mathrm{t} /$ ha of cattle manure and 50 $\mathrm{kg} / \mathrm{ha}$ of NPK (11-22-16) fertilizer were applied. Seedling was thining 10 days after germination in order to ensure a population of one seedling per pole with final density 25000 plant /ha. All the plots were cultivated on the same day (16/09/2016) and then sown 15 days later (30/09/2016). Two (2) weedings were carried out 15 days and 35 days after germination and two fertilizations with urea were carried out 17 days and 37 days after emergence at a rate of $100 \mathrm{~kg} \mathrm{~N} / \mathrm{ha}$. This study begins in october with is the ending month of cold dry season but rain did not begin. The crops were watered at a rate of $50 \mathrm{~mm} /$ day with manual watering cans. The irrigation dose is divided into two parts at a rate of $25 \mathrm{~mm}$ in the morning and $25 \mathrm{~mm}$ in the evening for five (5) days on seven (7) during the week, this during 25 days before the onset rains.

\section{Evaluation of root number}

The cultural profile method according to Chopart (1999) was used.
The aim was to highlight the characteristics of the various layers of the soil, to examine how they are exploited by the roots and to evaluate, as far as possible, the causes of their differences (Chopart, 1999). A profile pit of $150 \mathrm{~cm} \times 60 \mathrm{~cm}$ was perpendicularly dug for each treatment, with a vertical wall $10 \mathrm{~cm}$ from each plant of maize. This explains the roots of two plants of maize on each side, a total of four (4) feet of maize per pit. A grid of $100 \mathrm{~cm} \times 50 \mathrm{~cm}$ gridded every $2 \mathrm{~cm}$ had been placed on the profile. Then, the root impacts were positioned and counted, as well as the root diameters were measured in each square of the grid with a caliper (Figure 2).

\section{Statistical analysis}

An analysis of variances was carried out on the depth, width and root area concentration data. The Newman and Keuls test were used for the multiple comparison of means. These statistical analyzes were performed using software RStat. The differences were considered significant at $95 \%$ confidence level $(p<0.05)$.

\section{RESULTS}

\section{Root measurements and orientation}

The analysis of variances in the extension of maize roots according to the different layers and methods of ploughing are presented in Table 2.

It is noted from Table 2 that the treatment $L 2$ facilitated deeper root development, followed by L4, L0 and L1 respectively and then $L 3$. The $L 2$ treatment also lead to the greatest lateral root development. It is followed by LO and L4, L3, and finally by L1. Moreover, the horizon difficult to cross is shallower on the plots of $L 1$ and $L 3$. This horizon is deeper in succession for treatments $L 0$, L2 and L4.

\section{Behavior of roots according to soil horizons}

Table 3 presents the variation of root surface area, root depth, and root form development.

A significant difference is observed between treatments for the different parameters. Thus, L4 offers the largest root concentration zone, followed by $\mathrm{L} 2$ and L3, L0, L1. Moreover, the depths of appearance of the first roots and 

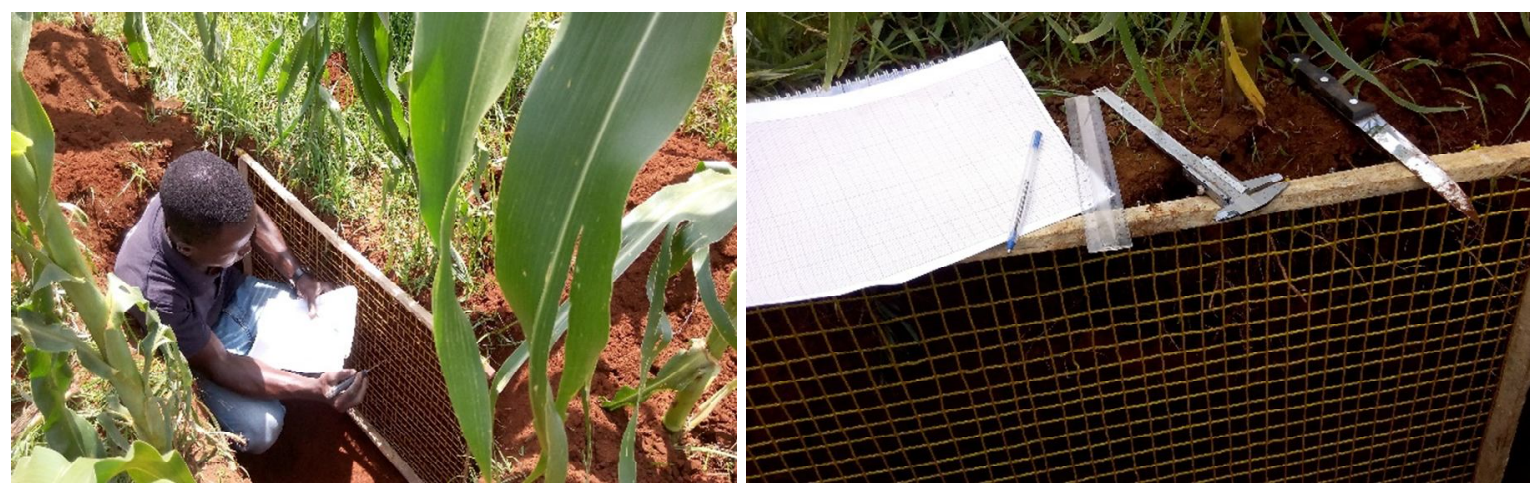

Figure 2. Root number evaluation method.

Table 2. Comparison of maximum depth and root width development, hard horizon to cross through roots and direction of large roots.

\begin{tabular}{ccccl}
\hline & $\begin{array}{c}\text { Maximun depth of root } \\
\text { development }(\mathbf{c m})\end{array}$ & $\begin{array}{c}\text { Maximum width of root } \\
\text { development }(\mathbf{c m})\end{array}$ & $\begin{array}{c}\text { Hard horizon to cross } \\
\text { through roots } \mathbf{( c m})\end{array}$ & $\begin{array}{l}\text { Direction of } \\
\text { large roots }\end{array}$ \\
\hline L0 & $31.50 \pm 1.1^{\mathrm{c}}$ & $45.25 \pm 2.4^{\mathrm{b}}$ & $43.90 \pm 0.27^{\mathrm{a}}$ & Vertical \\
L1 & $30.25 \pm 1.1^{\mathrm{c}}$ & $30.00 \pm 1.8^{\mathrm{d}}$ & $27.38 \pm 0.48^{\mathrm{d}}$ & Spread \\
L2 & $38.00 \pm 1.9^{\mathrm{a}}$ & $54.00 \pm 1.4^{\mathrm{a}}$ & $37.94 \pm 0.13^{\mathrm{b}}$ & Scattered \\
L3 & $27.13 \pm 0.9^{\mathrm{d}}$ & $40.75 \pm 1.5^{\mathrm{c}}$ & $27.48 \pm 0.55^{\mathrm{d}}$ & Scattered \\
L4 & $34.25 \pm 1.8^{\mathrm{b}}$ & $45.00 \pm 1.4^{\mathrm{b}}$ & $35.85 \pm 0.83^{\mathrm{c}}$ & Scattered \\
\hline
\end{tabular}

Each value is a mean ( \pm standard deviation) of 3 replicates. In the same column, values followed by a different letter are significantly different $(P<0.05)$ according to Newman and Keuls test.

Table 3. Comparison of the area of root concentration, depth of occurrence and root form development.

\begin{tabular}{lccl}
\hline Treatments & $\begin{array}{c}\text { Area of root } \\
\text { concentration }\left(\mathbf{c m}^{2}\right)\end{array}$ & $\begin{array}{c}\text { Depth of first roots } \\
\text { apparition } \mathbf{( c m})\end{array}$ & Root form development \\
\hline L0 & $80.00 \pm 6.68^{\mathrm{c}}$ & $7.25 \pm 0.65^{\mathrm{a}}$ & Half-sphere \\
L1 & $73.75 \pm 17.93^{\mathrm{c}}$ & $5.38 \pm 0.48^{\mathrm{b}}$ & Half-sphère \\
L2 & $147.58 \pm 32.92^{\mathrm{b}}$ & $5.99 \pm 0.52^{\mathrm{b}}$ & Funnel \\
L3 & $106.83 \pm 30.24^{\mathrm{c}}$ & $5.68 \pm 0.39^{\mathrm{b}}$ & Funnel \\
L4 & $214.50 \pm 18.57^{\mathrm{a}}$ & $3.81 \pm 0.24^{\mathrm{c}}$ & Half-sphere \\
\hline
\end{tabular}

Each value is a mean ( \pm standard déviation) of 3 replicates. In the same column, values followed by a different letter are significantly different $(P<0.05)$ according to Newman and Keuls test.

the root development form have differed slightly between treatments. Figure 3 shows the distribution of the number of roots according to the depth, for all the degrees of soil work.

There is a difference in the number of roots between the horizons with a marked decrease in the number of roots with depth. The amounts of roots at each horizon are summarized in Table 4.

There is a decreasing distribution of the total number of roots for treatments L1, L2 and L3. Then a greater number of roots between 10 and $20 \mathrm{~cm}$ for the L0 and L4. In the other word, a more marked presence of the number of fine roots at L4, L3 and L2 is observed beyond $20 \mathrm{~cm}$.

\section{Relationship between soil density and number of maize roots}

Figure 4 presents the distribution curve of the number of roots as a function of the apparent density of the soil every $10 \mathrm{~cm}$ over the depth 0 to $30 \mathrm{~cm}$.

There is a nonlinear relationship between the apparent soil density and the number of roots developed by maize. The polynomial regression leads to the following regression equation:

$$
y=16.2 x^{3}-519.6 x^{2}+5524 x-19366.5 \text { with } R^{2}=0.55
$$

Even if the coefficient of determination appears to be low, 

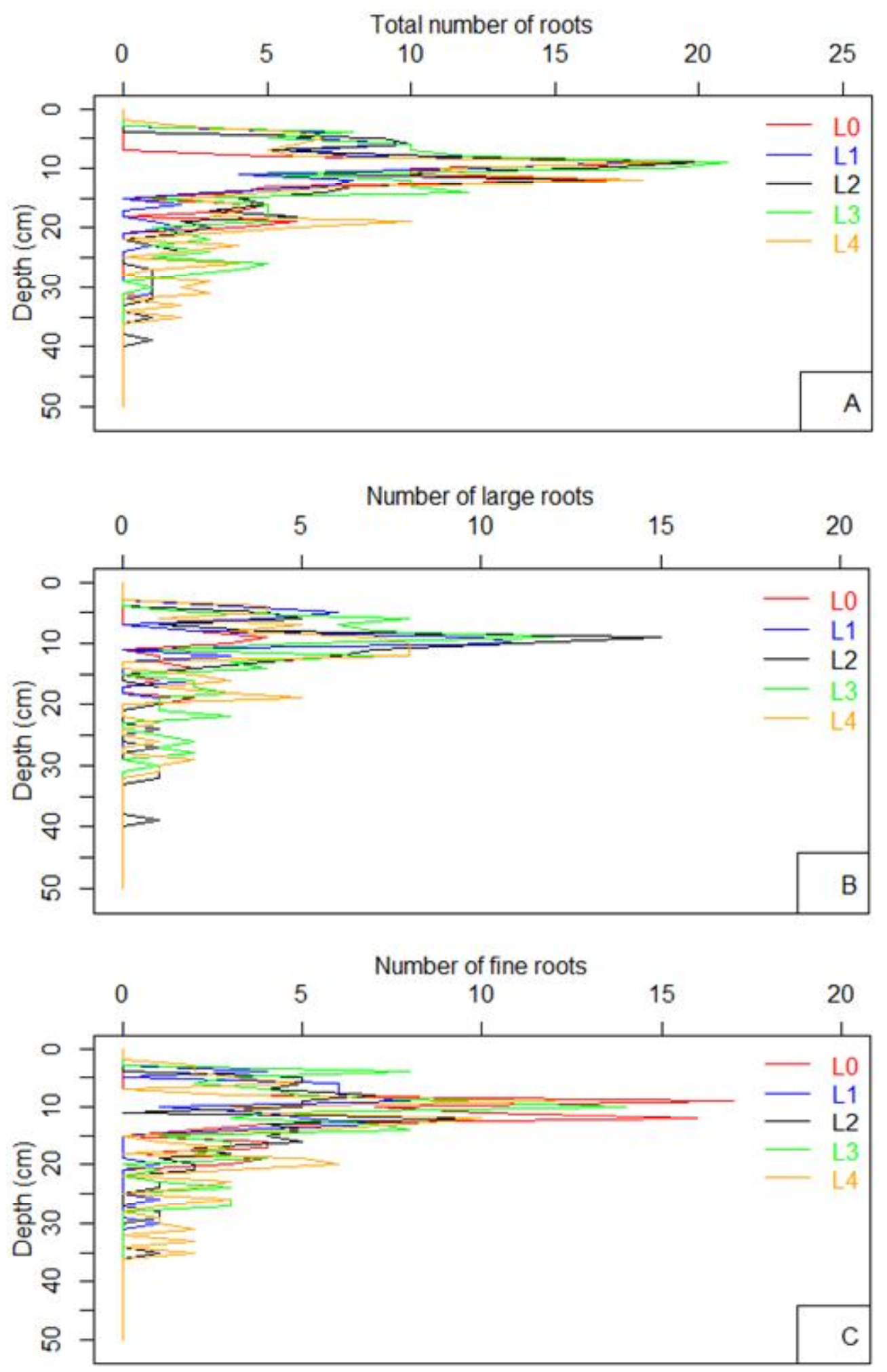

Figure 3. Distribution of number of roots by depth and method of ploughing.

there is a threshold from which the root density becomes inversely proportional to the apparent soil density. Thus, in each horizon $10 \mathrm{~cm}$ thick to less than $30 \mathrm{~cm}$ deep, the maximum root development of about 67 roots is reached when the apparent soil density is close to $9.8 \pm 1.0$ $\mathrm{kN} / \mathrm{m}^{3}$. 
Table 4. Evolution of the number of roots according to depths and treatments.

\begin{tabular}{lcccccc}
\hline & Depth $\mathbf{( c m})$ & L0 & L1 & L2 & L3 & L4 \\
\hline \multirow{4}{*}{ Total number of roots } & $0-10$ & 36 & 67 & 71 & 85 & 62 \\
& $10-20$ & 55 & 27 & 61 & 59 & 72 \\
& $20-30$ & 2 & 3 & 9 & 22 & 19 \\
& $30-40$ & 1 & 1 & 4 & 0 & 7 \\
Number of large roots $(\mathrm{d}>0.5 \mathrm{~mm})$ & $0-10$ & 9 & 36 & 40 & 40 & 32 \\
& $10-20$ & 8 & 7 & 25 & 24 & 30 \\
& $20-30$ & 2 & 2 & 3 & 11 & 5 \\
& $30-40$ & 1 & 0 & 3 & 0 & 1 \\
Number of fine roots $(\mathrm{d} \leq 0.5 \mathrm{~mm})$ & $0-10$ & 27 & 31 & 31 & 45 & 30 \\
& $10-20$ & 47 & 20 & 36 & 35 & 42 \\
& $20-30$ & 0 & 1 & 6 & 11 & 14 \\
\hline
\end{tabular}

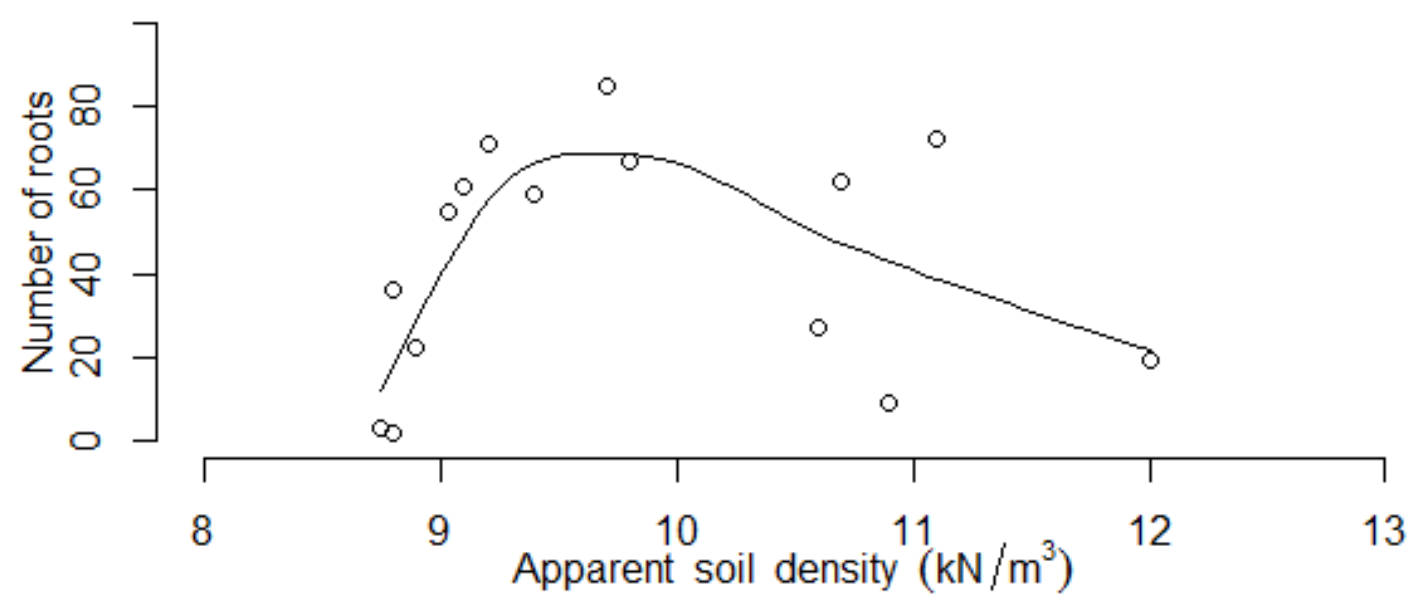

Figure 4. Relationship between soil density and number of maize roots.

\section{DISCUSSION}

\section{Depth and width of root development}

Ploughing with animal traction favored vertical and lateral root development (Table 2). In the case of the lateral extension, the "scattered" direction of the large roots was only possible due to medium-sized clods left after animal traction. This increased the depth of appearance of the layer hard to cross seems to have facilitated the vertical root development. This has contributed to the high rate of infiltration, making the soil to dry faster and justifying the deeper root development of maize on dry soil (Jordan, 1987a). The depth of ploughing did not significantly favor the vertical root development for ploughing with the tractor. This is due to the fact that the substrate opposes a purely mechanical resistance to root penetration, which is most when granulometry is fine and the soil residual moisture content is low. It reaches its maximum value for a soil containing less than $18 \%$ water and more than $40 \%$ clay, the nature of which is of no importance (Maertens, 1964). This situation is accentuated by the presence of a horizon hard to cross by the roots. This greatly limited the depth of root development observed at L3 and L1. This can be compared to the shading effect showed by Tardieu and Manichon (1987) when they found that barriers to root penetration reduce root density not only in the compacted zone but also in the uncompacted underlying soil. Despite the position of this horizon at $43.90 \pm 0.27 \mathrm{~cm}$, the vertical root development of LO was limited to $31.50 \pm 1.1 \mathrm{~cm}$ with vertical roots. It is therefore assumed that in the absence of this layer, the plowed plots would lead to a higher vertical root development compared to the treatment LO. This could complement the dominant role played by the seminal roots in the establishment of the root system in a situation of 
constraint according to Groleau-Renaud (1998) who said that these roots very strongly involved in the supply of water and nutrients to the young were significantly modified by mechanical stress.

\section{Behavior of roots according to soil horizons}

The results of Table 3 indicate that the explored surface by the majority of roots is strongly related to the degree of mechanization. Thus, ploughing with the tractor (L4) created a better extension condition for the roots (wider area of concentration). This facilitated the nutrients capturing over a large area, especially with the root development in the semi-sphere which is most effective in terms of exploration of the environment, since the interrow along its entire height is accessible. The treatments L3 (cultivator) and L2 (animal traction) have also led to a no less important surface explored by the roots with however a root development in the form of a funnel which suggests a follow-up of the large pores left by the clumps of earth resulting from these two degrees of ploughing. Despite the distribution in the form of a half-sphere in manual ploughing (L1) and no-tillage (L0), the great majority of the roots could not explore a large area. All this highlights the effect of the depth of the ploughing and the refining of the clods on the root extension. This is certainly a consequence of the clay soil content because high clay soils can significantly limit vertical root development (Thomas, 2000) and the decrease in root density would be proportional to the increase in clay of a given horizon (Sudmeyer et al., 2004). Although genetics have an impact on the type of root development, root distribution depends on many other factors, including soil fertility, cropping techniques and soil constraints (Drénou, 2006). For root distribution according to depth, the concentration of roots in the first layers $(0$ to $15 \mathrm{~cm}$ ) may be related, on the one hand, to the high organic material content of the soil and to fertilizer inputs, and on the other hand to regular precipitation during the vegetative period of the crop. According to Tamia et al. (1999), the decrease of the total root number according to the depth of root development as observed for treatments L1, L2 and L3 can be explained by the variation of the structural state of the soil to the ploughing depth; or may be by the natural decrease of the number of root development with depth (Tardieu and Manichon, 1987). The high number of the roots (large and fine) between 10 and $20 \mathrm{~cm}$ deep for L4, L3 and L2 would also be a consequence of the the soil loss by these different ploughing at this depth. The observed variations in LO may be explained by the fact that in clay soils where the density of the material is very high, the roots penetrate only in the cracks or in the traces of ancient roots in the process of decomposition (Drénou, 2000). Thus, the depth and number of root development are strongly affected by exogenous factors, mostly the texture, structure, bulk density and stoniness
(Charnet, 2003).

\section{Relationship between soil density and number of maize roots}

The polynomial relationship between the apparent soil density and the maize root number reflects both the positive and negative contribution of soil density to maize root development (Figure 2). The weakest colonization of the horizons by maize roots was observed at the level of the insufficiently packed plots (Nicoullaud et al., 1995). Thus, maize cultivation requires a minimum of density (soil compaction) to express its potential for root development. However, this soil density required by maize plant can not grow exponentially because, under poor aeration conditions, consequent to insufficient porosity or filling of pores with soil water, root respiration would be greatly diminished; which would have a depressive effect on the development of the whole plant (Jordan, 1987b). Excessive compaction affects the physical properties of the soil. The pore size is reduced, which increases the hardness (or resistance) of the soil, with changes in water and air flow (Agrawal, 1991). In addition to that, maximum root development is only achieved for apparent soil densities close to $9.8 \pm 1.0$ $\mathrm{kN} / \mathrm{m}^{3}$. However, this density is given priority only with treatments L1, L2 and L3. This demonstrates the high soil density conferred by soil cultivation L4, which is certainly due to the refining of the soil, and the excess porosity caused by no-tillage on clay-loam soil, as a consequence of possible shrinkage cracks during the period dry or galleries from biological activities (earthworms, old roots in decompositions).

\section{CONCLUSION}

Different degrees of mechanization of tillage have influenced the root system of maize on andosols. On these soils, ploughing with animal traction and the cultivator without soil refinement contributes to a better root development of maize. Ploughing with the tractor followed by the disc harrow favors the depth and shape of root development without, however, having a strictly positive impact on the overall root development. Compared to no-tillage, maize root development is virtually unaffected by manual ploughing with angady. All its variations result from the modifications brought by each degree of mechanization of the tillage on the physical properties of clay-loam soils. However, our results can be taken as preliminaries and be continued with another studies.

\section{ACKNOWLEDGMENT}

The author thanks the European Union for funding this 
work through the PAFROID intra-ACP mobility grant.

\section{REFERENCES}

Agrawal RP, 1991. Water and nutrient management in sandy soils by compaction. Soil Tillage Res, 19: 121-130.

Andriamanantena $Z, 2006$. Biomasse racinaire des plantes sous différents systèmes de culture : labour et semis direct sous couverture végétale dans le Vakinankaratra. Mémoire de fin d'étude pour obtenir le diplôme d'ingénieur Agronome, Ecole Supérieure des Sciences Agronomiques, Université d'Antananarivo-Madagascar.

Charnet F, 2003. L'enracinement des arbres et les propriétés physiques des sols. Forêt-entreprise. 154: 37-43.

Chopart JL, 1999. Relation entre état physique du sol, système racinaires et fonctionnement hydrique du peuplement végétal : outils d'analyse in situ et exemples d'études en milieu tropical à risque climatique élevé. Thèse de Doctorat. Université de Grenoble 1 (Joseph Fourier) (Sciences de la Terre) / Grenoble / France.

CPCS, 1967. Classification des sols. Commission de Pédologie et de Cartographie des sols. Edition 1967. Numérisé par l'Association Française pour l'Etude du Sol (www.afes.fr - 2011) pour mise à disposition de la communauté (avec corrections de Denis Baize). 100 p.

CPSA, 2016. Centre de Production de Semence d'Agnarafaly. http://semences dusud.com/station/cpsa.htm. Consulté le 14/09/2016.

Drénou $C, 2000$. Étude des relations entre systèmes racinaires et stabilité des arbres. Les Dossiers de l'environnement de l'INRA, 20: 153-159.

Drénou C, 2006. Les racines : face cachée des arbres. Paris : Institut pour le développement forestier. $335 \mathrm{p}$.

FAO and Unesco, 1975. Carte mondiale des sols. Volume I, Légende. Paris, $1975.68 \mathrm{p}$.

FAO, ISRIC and AISS. 1999. Base de référence mondiale pour les ressources en sols. Rapport sur les ressources en sols du monde. M51_ISBN 92-5-304141-9. 101 p.

Groleau-Renaud V, 1998. Contrainte mécanique et exsudation racinaire du maïs : incidence de la morphologie du système racinaire. Thèse de doctorat en Sciences Agronomiques à l'Institut National Polytechnique de Lorraine.

Jenhaoui Z, Raclot D, 2011. Le travail du sol dans le bassin versant de Kamech. Rapport de travail, Institut de Recherche pour le Développement, IRD Tunis. $23 \mathrm{p}$.

Jordan MO, 1987a. Mise en place du système racinaire du maïs. I. Importance de quelques paramètres relatifs à la plante. Agronomie, EDP Sciences, 7(6): 365-371.

Jordan MO, 1987b. Mise en place du système racinaire du maïs. II. Importance de quelques paramètres relatifs aux conditions de milieu. Agronomie, EDP Sciences, 7(7): 457-465.

MAEP, 2003. Monographie de la Région de Vakinankaratra. Ministère de l'Agriculture, de l'Elevage et de la Pêche. Antananarivo. 118 p.

Maertens C, 1964. La résistance mécanique des sols à la pénétration : ses facteurs et son influence sur l'enracinement. Ann Agron, 15: 539554.

Nicou R, Charreau C, Chopart JL, 1993. Tillage and soil physique properties in semi-arid west Africa. Soil Till Res, 27: 125-147.

Nicoullaud B, Dartout R, Duval O, 1995. Etude de l'enracinement du blé tendre d'hiver et du maïs dans les sols argilo-limoneux de Petite Beauce. Dans: Etude et Gestion des sols, 2(3):183-200.

Raboin LM, Ramanantsoanirina A, Dzido JL, Frouin J, Radanielina T, Tharreau D, Dusserre J, Ahmadi N, 2013. Création variétale pour la riziculture pluviale d'altitude à Madagascar : bilan de 25 années de sélection. Cah Agric, 22(5): 450-458.

Sudmeyer RA, Speijers J, Nicholas BD, 2004. Root distribution of Pinus pinaster, $P$. radiata, Eucalyptus globulus and E. kochii and associated soil chemistry in agricultural land adjacent to tree lines. Tree Physiology, 24: 1333-1346.
Tamia A, Moreau R, Fortier M, Yoro G, 1999. Influence du travail du sol sur l'évolution physique d'un sol forestier ferrallitique après défrichement motorisé. Conséquence sur l'enracinement du maïs. Etude et Gestion des Sols, 6(1): 14.

Tardieu F, Manichon H, 1987. Etat structural, enracinement et alimentation hydrique du maïs. II. - Croissance et disposition spatiale du système racinaire. Agronomie, EDP Sciences, 7(3): 201-211.

Thomas FM, 2000. Vertical root development patterns of mature Quercus trees growing on different soil types in northern Germany. Plant Ecology, 147: 95-103.

Wambeke AV, Louis A, Ameryekx J, Aissoug M, 1986. Clés de la taxonomie des sols. Traduction de "Keys to Soil Taxonomy". Monographie Technique $\mathrm{N}^{\circ} 13,1986.350 \mathrm{p}$.

Zoelinirina ZP, 2007. Caractérisation du système racinaire du riz pluvial : mise au point d'une méthode, effets de conditions de culture, dynamique et relation avec le fonctionnement de la culture. Mémoire de fin d'étude pour obtenir le diplôme d'ingénieur Agronome, Ecole Supérieure des Sciences Agronomiques, Université d'AntananarivoMadagascar.
Citation: Dayou ED, Zokpodo, BL, Rakoto, B, 2017. Effects of different tillage methods on maize (Zea mays $L$.) root development in andosol. Net J Agric Sci, 5(2): 23-30. 